\title{
Methodological challenges and issues of recruiting for mental health and substance use disorders trials in primary care
}

\author{
Anne Marie Henihan ${ }^{1}$, Jan Klimas ${ }^{2,3}$, Gerard Bury ${ }^{2}$, Thomas OToole ${ }^{4}$, Traci Rieckman ${ }^{5}$ Gillian Shorter ${ }^{6}$, \\ Walter Cullen ${ }^{1,2^{*}}$
}

From 2014 Addiction Health Services Research (AHSR) Conference

Boston, MA, USA. 15-17 October 2014

\section{Background}

Poor recruitment to controlled trials is a frequently reported problem. Challenges related to study design, communication, participants, interventions, outcomes, and clinician workload hinder recruitment, and the effectiveness of interventions used by trialists to increase recruitment rates is unknown.

\section{Objectives}

To explore the methodological challenges and issues in recruiting for mental health and substance use disorder trials in primary care, and to consider how these methodological challenges can be addressed.

\section{Method}

The presentation will recount the authors' experience of recruiting for cluster randomized trials in primary care. Methodological challenges, such as clarity of instruction, patient characteristics, patient-doctor relationship, effects of intervention on patients and clinic, and personal benefits for clinicians will be described. The authors will consider how these might relate to and be used for peer learning and peer support in primary care research.

\section{Conclusion}

The presentation will conclude with an overview of how lessons learned from past studies may be used to improve recruitment for trials of mental health and substance use disorders in primary care.

\footnotetext{
* Correspondence: walter.cullen@ucd.ie

${ }^{1}$ Graduate Entry Medical School, University of Limerick, Limerick, Ireland
}

Full list of author information is available at the end of the article

\begin{abstract}
Acknowledgements
Grants support from the Irish Research Council: Supporting empiric research and capacity building on brief interventions and their delivery in primary care (PINTA-TOUR), and ELEVATE: Irish Research Council International Career Development Fellowship - co-funded by Marie Curie Actions (ELEVATEPD/ 2014/6). GS's time is partly funded through the MRC grant "Development of a Methodology Hub for the island of Ireland" (G0901530).
\end{abstract}

\section{Authors' details}

'Graduate Entry Medical School, University of Limerick, Limerick, Ireland. ${ }^{2}$ School of Medicine and Medical Science, University College Dublin, Coombe Family Practice, Dublin 8 , Ireland. ${ }^{3}$ Addiction \& Urban Health Research Initiative, BC Centre for Excellence in HIV/AIDS, Vancouver, BC, Canada, V6A 1H2. ${ }^{4}$ Department of Medicine, Providence VA Medical Center, Providence, Rl, 02908, USA. ${ }^{5}$ Department of Public Health and Preventive Medicine, Oregon Health \& Science University, Portland, OR, 97239-3098, USA. ${ }^{6}$ Bamford Centre for Mental Health \& MRC, All Ireland Trials Methodology Hub, University of Ulster, Londonderry, Northern Ireland.

Published: 20 February 2015

doi:10.1186/1940-0640-10-S1-A21

Cite this article as: Henihan et al:: Methodological challenges and issues of recruiting for mental health and substance use disorders trials in primary care. Addiction Science \& Clinical Practice 2015 10(Suppl 1):A21.

Submit your next manuscript to BioMed Central and take full advantage of:

- Convenient online submission

- Thorough peer review

- No space constraints or color figure charges

- Immediate publication on acceptance

- Inclusion in PubMed, CAS, Scopus and Google Scholar

- Research which is freely available for redistribution

Submit your manuscript at www.biomedcentral.com/submit

\section{() Biomed Central}

